\title{
Reformed Churches in South Africa's strategies for poverty reduction in urban communities
}

\begin{abstract}
Author:
Motshine A. Sekhaulelo

Affiliation:

${ }^{1}$ Faculty of Theology,

University of Pretoria,

South Africa

Correspondence to:

Motshine Sekhaulelo

Email:

amos.motshine@gmail.com

Postal address:

PO Box 255, Ga-Rankuwa

0208, South Africa

\section{Dates:}

Received: 20 Dec. 2013

Accepted: 17 June 2014

Published: 15 Dec. 2014

How to cite this article:

Sekhaulelo, M.A., 2014,

'Reformed Churches in

South Africa's strategies for poverty reduction in urban communities', In die Skriflig 48(1), Art. \#1788, 10 pages. http://dx.doi.org/10.4102/ ids.v48i1.1788

Note:

The author is the Minister of the Word at the Reformed Church Mmakau. This article is based on research done for a doctoral thesis submitted in the Faculty of Theology of the University of Pretoria

\section{Copyright:}

(C) 2014. The Authors. Licensee: AOSIS

OpenJournals. This work is licensed under the Creative Commons Attribution License.
\end{abstract}

\section{Read online:}

This article investigates and outlines the strategies, which the Reformed Churches in South Africa (RCSA) can employ for poverty alleviation in the South African urban communities. ${ }^{1}$ By RCSA, the author refers to the local churches that constitute a family of churches or church organisation. It is important to note that, historically, the churches stood at the forefront of giving freely to the poor, caring for widows, taking in destitute orphans, visiting the sick, and caring for the dying. Despite this long and often appreciated legacy of support for the poor and the needy, the church ceased or slowed to provide such ministry. This was probably due to the emphasis on the 'social gospel' in liberal theology, which many churches began to view with deep suspicion. In talking about the church's stance towards poverty, it should also be noted that, historically, the poor have suffered due to those churches that, without warrant, preach the health, wealth and prosperity gospel, incorrectly stating that God wants everyone to be equally rich. By promoting false hope about the prospects for overnight success through prayer and tithing, some of these churches take advantage of a vulnerable congregation that is often desperate for an improvement in their economic circumstances. This article investigates not only the complex of poverty and inequality in the South African (SA) urban community, but also the prophetic calling of the RCSA with respect to poverty today. The conclusion arrived at is that poverty and inequality persist in the urban community whilst the church, both as institution and organism, should be able to study and respond positively to the dynamics involved in urban poverty.

Die Gereformeerde Kerke in Suid Afrika (GKSA) se strategieë vir armoedeverligting in stedelike gebiede. Hierdie artikel ondersoek en skets die strategieë wat die GKSA kan benut om armoede in stedelike gebiede te verlig. Die GKSA verwys na plaaslike kerke wat 'n familie van kerke of kerkorganisasies uitmaak. Dit is belangrik om kennis te neem van die feit dat die kerk, reg deur die geskiedenis, op die voorpunt was om vryelik aan armes te voorsien, vir die weduwees te sorg, weeskinders in te neem, siekes te besoek en sterwendes te versorg. Ten spyte van hierdie lang en meestal gewaardeerde nalatenskap aan armes en behoeftiges, het hierdie bediening deur die kerk afgeneem en is in baie gevalle gestaak. Dit is waarskynlik as gevolg van die klem wat in die bevrydingsteologie op die 'sosiale evangelie' geplaas is en tans deur baie kerke met agterdog bejeën word. Wanneer die kerk se houding teenoor armoede ter sprake kom, moet 'n mens in gedagte hou dat, histories gesproke, die armes as gevolg van die kerk ly - kerke wat sonder waarborg die gesondheidsen voorspoedteologie verkondig het en wat valslik voorgegee het dat dit God se wil is dat almal ewe ryk moet wees. Deur die vals vooruitsigte voor te hou om oornag deur gebed en uit offergawes ryk te word, is kwesbare gemeentelede wat desperaat was vir die verbetering van hulle ekonomiese omstandighede uitgebuit. Hierdie artikel ondersoek nie net die kompleksiteit van armoede en ongelykhede in die stedelike gemeenskappe van Suid-Afrika nie, maar ook die profetiese roeping van die GKSA met betrekking tot armoede vandag. Die gevolgtrekking is dus dat armoede en ongelykheid voortduur in stedelike gebiede terwyl die kerk as instituut sowel as organisme die bevoegdheid moes hê om die dinamiek wat deel van stedelike armoede uitmaak, te bestudeer en positief daarop te reageer.

\section{Introduction}

The most disquieting overall finding in the government's National Planning Commission Diagnostic Report released in June 2011 is that poverty and inequality persist. This means that, despite a commitment to promote the progressive realisation of socio-economic rights as set out in the national constitution, the majority of South Africans remain poor and marginalised 
(cf. Ramphele 2012:3a). Beall and Fox (2009:113) summarise the key characteristics of urban poverty and vulnerability as follows:
A reliance on a monetised economy;
A reliance on employment in the informal economy;
Poor - quality housing;
Insecurity of tenure (for both owners and tenants);
Lack of access to basic infrastructure and affordable housing;
Susceptibility to diseases and accidents;
Environmental hazards, including the impact of natural and man-made disasters.

A comprehensive study conducted in 2011 indicated that inequality is very high in the South African urban community (Chanderdeo et al. 2011). Pottinger (2008:71a) wrote that it must be admitted that some of this inequality, has been ameliorated by the creation of the South African welfare state. The South African Social Security Agency (Sassa) indicated that just fewer than 14.5 million people receive grants, with 9.9 million of these receiving a child support grand. The rapid growth of these grants indicates that more than a quarter of all South Africans receive some form of social grant (cf. Biko 2013:202a; Plaut \& Holden 2012:232). The main objective of this article is to outline the strategies, which the RCSA should employ to help poor people in the urban centres to earn their way out of poverty. In order to reach these objectives, the following will be dealt with:

the definition of poverty and inequality; causes of poverty in urban areas; biblical and theological perspective on poverty; Kingdom theology; the relationship between the church and the Kingdom; the relevance of the gospel of the Kingdom of God for the problem of poverty; RCSA strategies with respect to poverty today.

\section{A definition of poverty}

According to Williams (1998:3), poverty is never a simple matter. It is a complex of physical and spiritual pain, which robs the person and the community of dignity and meaning as much as it deprives the body of nourishment, shelter and beauty. Poverty is about the lack of material or social resources such as access to information, education, health care, social status, political power, and the opportunity to develop meaningful connections with other people in society. The term inequality simply refers to the unequal distribution of income and assets (or possessions) between different individuals and groups in a country (Haralambos \& Holborn 1995:125a; Astley 2000:68).

\section{Causes of poverty in urban areas}

Having described some of the economic realities of the context, one should raise the question of the cause of poverty and inequality. This is not only a difficult venture, but also controversial. Silvoso (2007:118a) states that, throughout the Old Testament, the penalty for idolatry took the form of famine, pestilence or drought (cf. Dt 28:15-29). The brunt of such judgment was always felt in the marketplace and particular in the stomachs of people. Food became scarce and eventually insufficient. Two things can cause this insufficiency: a divine judgment as a result of sin, or an evil system that enables a few to hoard resources at the expense of many (cf. Linthicum 1991:24; Mutavhatsindi 2008:27).

Today, the situation is no different. It is true that some people are poor, because they are lazy and do not avail themselves of the opportunities presented (cf. Grigg 1990:31). It is also true that political policies to a large extent also cause poverty and the economic ills (or welfare) of society (Is 14:5-21; Jr 50:2-17; 51:6-10; Dn 3:1-7; Rv 17:1-6; 18:2-19). The serious misuse of the economy was equal to the sin of idolatry (Jr 3:8; 29:23; Ek 16:32; 23:37). Hence, the prophets of the Old Testament felt strongly about this issue and often spoke out against the abuse of power and the suffering it caused (cf. Strydom \& Wessels 2000:22).

To solve the first case requires personal and corporate repentance, which opens the door for God to intervene. The second has to be dismantled by the church, firstly, within its own ranks where mind-sets need to be changed and transforming patterns of behaviour established; and secondly, in society until it has been transformed (cf. Silvoso 2007:119; Pawson 2007:529). The most apparent causes of poverty in the South African urban community today are the following.

\section{Unemployment}

Tonna (1982:17) writes that unemployment is often the first harsh reality that dissipates the hopes of the immigrant, newly arrived in the third world metropolis. Many of those who come to the city to seek work do not find it, or if they do, it is not permanent. The unemployed often live with their relatives. Thus, the income of one worker may be used to sustain several other potential workers. This tends to depress the urban standard of living. South Africa is no exception. South Africa's formal unemployment rate sits at around 25\% and there is a huge pool of unemployed graduates.

Meredith (2010:520) asserts that only about half of the economically active South Africans have jobs in the formal sector. Several million more earn a living in the informal sectorhawkers, small traders, domestic workers and backyard businesses. Biko (2013:222b) mentions that the problem of unemployment amongst the youth in South Africa is acute and has worsened significantly over the two years after 2008 as a result of the recession. The result is that more than three million young people between the ages of 15 and 35 years are not in education, not in employment and not in training. Millions of youths live on the margins of the formal economy, their hopes and expectations unmet (Altbeker 2007:100).

Unemployment implies hunger, misery and a loss of selfesteem for those who are jobless. It may even result in anger and resentment against the system that has led to their inability to find a meaningful job. Furthermore, unemployment incurs multiple types of trauma and challenges the ability of individuals, families and communities to cope with the stress it engenders. Depleted life savings, bankruptcy and homelessness are but a few of the by-products of one or 
multiple spells of unemployment. These mountainous levels of unemployment are the product of several factors such as the following: firstly, the South African economy has become skills intensive, and those with the appropriate qualifications are in great demand, but owing to the low levels of literacy and numeracy, there is a lack of skilled workers in South African cities. The continuing under-performance of our education system has a disproportionate effect on poor people (Ramphele 2012:142). Meredith (2010:550) notes that businesses struggle to find employees with the correct skills. A high proportion of the estimated five million unemployed people possess no skills or training and have little prospect of ever finding a job. Haralambos and Holborn (1995:727b) suggested that the inescapable conclusion is that the most basic service most governments are expected to offer their people is an education. Hence, one of the largest international organisations, the World Bank, annually invests a large sum of money in education projects in developing countries. This is because they are convinced that the improvement of education in these countries can help to alleviate poverty, either directly or indirectly (see Shively 1997:74).

Secondly, the government, unconsciously though energetically, followed an economic strategy that diverts resources from investment to consumption. This is already beginning to show with the growing de-industrialisation of the country's economy (cf. Mbeki 2011:8). For instance, manufacturing, which constituted around a quarter of the economy in 1990 , fell back to $19 \%$ by 2000 and to $16 \%$ by 2005 (Gumede 2005:102).

Thirdly, South Africa's restrictive labour policies and strong unions are limiting the number of lower-skilled individuals that can be absorbed into the workforce. This situation was exacerbated during the latter half of 2008 and during 2009 when South Africa, like most other countries around the world, slipped into economic recession. Business failure accelerated with the resultant loss of jobs, and large companies considerably slowed the rate at which they employed new staff (Mbeki 2011:115). It is clear from the preceding that cities do not cope with the massive demand for employment. Even when new jobs are created, they are never sufficient to absorb the newly arrived immigrants. In South Africa, too, the number of immigrants to the cities exceeds the number of jobs available. A failure to resolve this challenge could have dire long-term consequences for the stability of the country.

Fourthly, one state of emergency that hampers poverty alleviation in South Africa today is the current HIV and AIDS pandemic. Large parts of the economically active workforce are infected (cf. Pottinger 2008:156). AIDS orphans and the cost related to their care as well as AIDS deaths in general decrease the means available for poverty alleviation (Garland \& Blyth 2005:143). Hence, in July 2003, a WorldBank report suggested that AIDS could lead to complete economic collapse once the cumulative generational effects were added in. 'If nothing is done to avert the epidemic then countries like South Africa ... could suffer a 50 per cent decline in their per capita GDP over three generations.' In the same way, an International Monetary Fund (IMF) report estimated that South Africans' life expectancy would drop from 64 to 37 years (Johnson 2009:206).

\section{Globalisation}

Globalisation can also be mentioned as one of the greatest influences with regard to poverty on the macro-level. This, in turn, influences the poverty that is experienced on the mesolevel. The term globalisation describes the modern process of the integration of international economic structures across national borders and political entities. This is the new imperialism, an economy distinct from the political and economic imperialism of the past and representing, in fact, the domination of politics by rich countries. There is no doubt that globalisation has made the rich countries richer and the poor poorer (whilst also widening the gap between rich and poor within each country) (Bauckham 2003:94).

\section{Economic strategy that enables a few to hoard resources at the expense of many}

When apartheid ended, there was virtually no African business class at all. There were taxi bosses, football bosses, shebeen operators, herbalists selling potions and magic cures, and those who ran the spaza shops (tiny retail outlets) in townships (cf. Johnson 2009:386b). It is essential to the wellbeing of our democracy to rapidly redress black South Africans' enforced exclusion from economic opportunities (Balshaw \& Goldberg 2005:16)). Clearly the most promising route would be via decisive improvements in the quality of African education, housing and health and the deployment of non-African professionals to pass on their skills to young black people.

Such path was either ignored or rejected. To date, the focus has been on a diagnosis of the racial symptoms of apartheid, resulting in a weak prescription of a Truth and Reconciliation Commission with a narrow mandate focused on crimes against humanity. Another point of focus was the prescription of a cocktail of Black Economic Empowerment (BEE) and affirmative procurement as a remedy for South Africa's economic ills (Biko 2013:4; cf. Malan \& Smit 2001:45). Gevisser (2009:220) states that Broad-based BEE is aimed at effecting a more equitable distribution of economic wealth and has been branded as the essential second wave of transformation after democratisation and the political miracle. There was hope trumpeted by some early BEE beneficiaries - that black people joining company boards would somehow create more jobs and alleviate poverty. However, what has happened in recent years is that it is primarily people close to the ruling party who are seen to be the main beneficiaries of this necessary strategy. This gives rise to allegations of nepotism and favouritism. The picture is one of the massive personal enrichment of a select few, and the creation of what is one of the most unequal societies on the planet. This is then perceived as being at the expense of 'the masses' (Feinstein 2007:246). The greatest fears about BEE concerned job creation and poverty alleviation. What we need are entrepreneurs, people who can start new businesses, take risks and create new jobs. 


\section{Biblical and theological perspective on poverty}

Our starting point in discussing biblical and theological principles regarding poverty must be creation. 'In the beginning God created the heavens and the earth - And God saw everything that he had made, and behold, it was very good' (Gn 1:1-31). Included in this good creation were human beings (Gn. 1:27). God gave human beings a special place in his creation: he made human beings stewards (or trustees or caretakers) of his creation (De Bruyn 1993:227). The Greek oikonomous, which is sometimes rendered as steward, is related to the English word economy, and can be found in several places in the New Testament (Mt 20:8; Lk 6:3; Rm 16:23; Pt 4:10).

Claerbaut (1983:13) describes stewardship as a response to earthly citizenship aimed at advancing justice and improving the quality of life in the neighbourhood, city and world. A crucial way for the church is to recognise that it is not foreign to the city. It was placed in the city by God to be its primary steward. Put differently, the city is a massive investment made by God and by humanity. Humanity provides for the stewardship of that city's political, economic, social and material investment through the system and structures of that city (Berkley 2000:12).

In spite of such a special place in creation, Adam and Eve disobeyed God. They rebelled, trying to take the place of God himself, rather than remaining as obedient stewards of his creation (Gn 3:1-7). The disruption of the relationship between human beings and God also disrupted the relationships between human beings themselves, as illustrated by the murder of Abel by his brother Cain (Gen 4:1-16). Amongst the other results of sin was the entrance of poverty into the world. However, God did not just abandon the world to sinful human beings. After their sin, Adam and Eve experienced the natural consequences of their rebellion (a desire to hide from God). God employed an 'aggressive evangelistic' strategy as he lovingly forced them to face their $\sin (\mathrm{Gn} 3)$.

Peters (1976:166) states that this strategy was conveyed to Adam and Eve as representatives of the race and involved the whole realm of human culture. In its widest sense, it includes religion. It serves humankind in their need as socio-religiocultural creatures. It includes the natural and social aspects of humankind such as habit, agriculture, industrialisation, commerce, politic, health, the social and moral order, academic and scientific advancement, education and physical care (cf. Kuiper 1991:182; cf. Van der Walt 2007:84a).

In reference to the above, Bernard (2004:12) remarks that God called Abraham and promised that, through him, all the families and nations of the earth would be blessed ( $\mathrm{Gn}$ $12: 3 ; 26: 4)$. The most significant dimension of the covenant with Abraham for biblical ethics was the promise of a people 'In you shall all the families of the earth be blessed.' From the one man Abraham and the one new nation that descends from him, God's blessing will overflow to all other nations (Yandian 1985:132; Wright 1995:127).
In the same vein, the Lord restrained poverty in the Old Testament era by means of the economic legislation that he gave to his people through Moses. For example, the Israelites were neither to charge interest on money lent to the poor (Ex 22:25) nor to show partiality to a poor person in a dispute (Ex 23:3). The poor were to be given the produce of the seventh year fallow field (Ex 23:11), and those who fell on hard times were to be helped ( $\mathrm{Lv}$ 25:23). Equally important, landowners and judges faced particular censure if they denied justice to the poor (Is 10:1-3). Judah's sins listed in Isaiah 58:6-10 included neglecting to give alms to the poor (Richardson 2007:32). These and other verses charge the Israelites with responsibility for the welfare of their poor (Ex 22:22; Dt 14:29, 24:19-22; Ps 82:3; Is 1:17).

In connection to this, Christ commands his disciples first to proclaim the gospel of repentance and salvation to the whole world (Mk 16:1), but then also to demonstrate practical concern for the poor (Mt 25:3246). As corroboration of Jesus' words, one of the first snapshots we have of life in the early church shows that '... there was not needy [poor] person among them [its members]' (Ac. 4:34). Basu (2005:45) states that they would not let a brother or sister suffer, be they widows or elderly people, orphans or homeless. Moreover, the apostles recognised the need for help when they instructed the congregation to choose seven men to assist in ministering to the widows. This freed them to give themselves to prayer and the ministry of the Word (Ac 6:1-7).

This was not a Jerusalem occurrence only, because many years later the church in Antioch sent financial help to the Christians in Jerusalem, and the Gentile churches of Greece also sent help to the Christians of Judea (Monsma 2006:83). In addition, James is abrasively critical of churches that made a distinction in their treatment of the rich and the poor. $\mathrm{He}$ points his readers to the truth that there is no distinction made in the Kingdom of God and that Christians should exercise impartiality in their welcome to all who come into their gatherings (Ja 2:1-7).

\section{Kingdom theology}

Despite the obvious important of the church, Silvoso (2007:157e) observes that Jesus touched on the subject only twice, in Mathew 16 and 18, using the word church only three times in the four Gospels. Even though Jesus did not talk much about his church - the subject of the Kingdom of God was ever present in his teaching. He either mentioned the Kingdom himself, or it was used in connection to him for a total of 69 times (cf. Pawson 2007:817b). Oliver and Thwaites (2001:31) correctly state that, on the two occasions when he discussed the church, he also spoke of the Kingdom, linking them from the very start: 'Upon this rock I will build My church; and the gates of Hades will not overpower it [and] I will give you the keys of the Kingdom of heaven' (Mt 16:18-19). Not only did he link the church to the Kingdom, but he also connected heaven to Earth, for he continues, 'And whatever you loose on earth shall have been loosed in heaven' (Mt 16:19; 18:18). 
In reference to the above, Maimela and König (1998:19) are of the view that the reign of God is deemed the essential feature in the words and deeds of Jesus. He both announces and realises the reign (Kingdom) of God, because he acts on behalf of God. Equally important, Van der Walt (2007:84) states that reformed theologians, including missiologists, use to emphasise the biblical, all-encompassing concept of the Kingdom of God. In essence, the Kingdom can be summarised in the following three facets: firstly, that God is sovereign King of his entire creation; secondly, that he rules creation through his will; and thirdly, that he confers his blessings on those who obey his laws (Berkhof 1996:76). This was done, for instances, in missiology (cf. Mashau 2004:166) and in ethics (cf. Forrester 1997:6; Vorster 2007:28-29.

In terms of a Christian worldview, these biblical perspectives about the Kingdom of God can be summarised by saying that people carry their religious convictions with them and reflect them in every phase of life, like in the political, economic, social and cultural life (cf. Kuiper 1991:182). In reference to the above, Van der Walt (1994:387) wrote that the gospel of Jesus Christ has power to change and renew all of life. It should also be pointed out that, historically, this concept (the Kingdom of God) was distorted by the liberation theology and the civil rights movement by stating that Jesus always identifies with the poor and the oppressed, giving them worth and dignity, and empowering them to build the Kingdom of God. Thus, the Kingdom of God will be an egalitarian society, in which all human beings will work in partnership with God and one another to break down the oppressive power structures of this world (Basu 2005:118). However, they tend to forget the words of Jesus Christ in John 18:36 where he said: 'I am not an earthly King. If I were, my followers would have fought when I was arrested ... my Kingdom is not of the world.'

\section{The relationship between the church and the Kingdom}

The specific relationship between the church and the Kingdom can be expounded under the following points.

The church is the object of the Kingdom: The church is not the subject, but the object of the Kingdom. Therefore, the church, in its suppressed situation, seeks preservation, support and shelter in God's government and it is looking forward to the fullness of God's Kingdom in the coming age. The Kingdom is thus related to the history of the church and the world alike. A connection exists between Kingdom and church, but they are not identical, even in the present age (Van der Walt 1991:354). A comprehensive study conducted in 1990 indicated that the Kingdom is the whole of God's redeeming activity in Christ in the world. The church is the assembly of those who belong to Jesus Christ (Douglas 1990:657).

The church is the instrument of the Kingdom: Ladd (1993:114) wrote that the church is the instrument of the Kingdom. The disciples of Jesus not only proclaimed the good news about the presence of the Kingdom, but they were also instruments of the Kingdom in that the works of the Kingdom were performed through them as through Jesus himself. It can be deduced that the word servanthood has a long history of being woven into the religious heritage of Israel and that it is a title, which befits Jesus. Even at this stage, one can see that this title is important when it is applied to the prophetic role of the church (Barclay 1995:161-162). Thus, the church, as a congregation of the believers, and individual Christians are servants (instruments) in service of the Kingdom of God.

Sanders (1997:29) asserts that the gospel of the Kingdom is best proclaimed by the church when, in the power of the Spirit of the King, it preaches, teaches and dedicates itself to authentic Kingdom activity in the confident hope that God's universal salvific reign of righteousness and peace will be manifest within the church itself amongst all humankind and over all creation. This is the context of the church's fervent prayer, 'Thy Kingdom come, Thy will be done, on earth as it is in heaven' (Mt 6:10). This implies that the church of Christ is the special covenant that exists through God's grace, in response to God's action in Jesus Christ. It also has, as its special calling, the proclamation in word and deed of God's inclusive covenant with its declaration of God's love and its demand for faith in God and love with justice towards all persons (Dake 1992:518; Allen 1995:287). With this as our background, what is the relevance of the gospel of the Kingdom of God for the problem of poverty?

\section{The relevance of the gospel of the Kingdom of God for the problem of poverty}

Jesus' opening words at the onset of his earthly ministry, 'The Spirit of the Lord is upon me, because He has anointed me to preach good news to the poor' (Lk 4:18, NIV), constitute a radical promise of tangible welfare to the needy. In addition, in Matthew 5:3 he says: 'Blessed are the poor in spirit, for theirs is the Kingdom of heaven.' Who are the 'poor' Jesus Christ spoke about? Those to whom he had been anointed to preach the good news of the Kingdom and to whom the Kingdom would be given (Lk 4:18ff.; cf. 7:22; cf. 6:20; Mt 11:5; 5:3;)?

They surely cannot be either just the materially poor (for Christ's salvation is not limited to the proletariat) or just the spiritually poor (for this overlooks his ministry to the need). He must have been referring to both in combination. For instance, Jesus said his children should not worry about what they will eat, drink or wear. He draws their attention back to the deepest secret of real, full life, to seek first the Kingdom of God and his laws (Mt 6:33) after which these secondary things will be given to them - as gifts (Mt 6:25). Of course, they need bread, but they cannot live by bread alone. They have to live from every Word (law) of God (cf. Mt 4:4). Furthermore, the exact words in the Lord's Prayer are 'Give us this day our daily bread' (Mt 6:11).

It is meant to be a predictable daily occurrence. The recipient must know, or at least have hope, that tomorrow is part of a continuum and not a crisis waiting to happen. The broader 
context points to a loving God as the source, our Father who art in heaven, and describes provision as a gift (Silvoso 2007:117). Equally important, Paul wrote that the Kingdom of God is not food and drink, but righteousness, peace and joy in the Holy Spirit (Rm 14:17). Richardson (2007:29) is of the view that to be 'poor in spirit', as expressed in Matthew 5:11, means to be humble and to be emptied of our spirit, not to hold on to things of our old nature. Simply put, the 'poor' are those to whom the Kingdom comes as great good news, partly because it is a free and unmerited gift of salvation to sinners, and partly because it promises a new society characterised by freedom and justice. By dispensing with the things of our former unregenerate state, we can receive the gifts of the 'Kingdom of Heaven'.

Ladd (1993:71) indicates that the Kingdom as God's gift may be further illustrated by a study of the word salvation. In the Gospels, the words to save and salvation refer both to an eschatological and present blessing. In Jesus' answer to the rich young ruler about eternal life, salvation is synonymous with eternal life and entrance into the Kingdom of God in the Age to Come (Mk 10:17-30). This eschatological salvation is also described merely as a saving of one's (true) life in contrast with losing one's physical life (Mt 10:39; Mk 8:35; Lk 17:33). This eschatological salvation can be described simply as entrance into (eternal) life (Mt 25:46; Mk 9:43) or into the joy of the Lord (Mt 25:21-23).

The church should exemplify both these truths. The church consists of the spiritually poor, the 'poor in spirit', who acknowledge their bankruptcy before God. They have no righteousness to offer, no merit to plead, no power to save themselves. They know that the only way to enter God's Kingdom is to humble themselves like little children and receive it as a gift. Moreover, the church should not tolerate material poverty in its own fellowship (Stott 2006:308). When Jesus said, 'The poor you will always have with you' (Mk 14:7), he was not acquiescing in the permanence of poverty. He was echoing the Old Testament statement, 'There will always be poor people in the land' (Dt 15:11). This was intended not as an excuse for complacency, but as an incentive to generosity, as a result of which 'there should be no poor among you' (Dt 15:4). This implies that, if there is one community in the world in which justice is secured for the oppressed, where the poor are freed from indignities of poverty, and where physical need is abolished by the voluntary sharing of resources, that community is the new Society of Jesus the Messiah (cf. Hiebert \& Meneses 1995:354).

The principle is found in Ephesians 4:28: 'He who steals must steal no longer; but rather he must labour, performing with his will have something to share with one who has need.' The afore said biblical verse describes the extraordinary social metamorphosis of a thief turned benefactor, a lawbreaker who decides not to steal anymore and chooses instead to work, learning an honourable trade to earn enough to care for him- or herself and to have extra to share with those in need.

\section{Reformed Churches in South Africa strategies with respect to poverty today}

Most reformed churches usually understand Christ's command in Matthew 28:19, as limited to the following: preaching the gospel; getting individuals converted and baptised (to become disciples); and establishing churches as communities of believers. If these churches could furthermore become self-governing, self-sustaining and self-propagating (making more disciples), their missionary task is usually regarded as completed. The social involvement of churches is regarded with suspicion and even viewed as deplorable 'social gospel' (Van der Walt 2007:78c). In view of this understanding, the calling of the RCSA, with respect to poverty, today will thus investigate the following elements: preaching the gospel; equipping members of the church; holistic approach; teaching work ethics; empowering the office of deacons; Christians organising themselves as an organisation or an institution; and encouraging cooperation between the church and state.

Preaching the gospel: In the 19th century, some Christian missions in China regularly offered a bowl of rice to people who attended church. The expression 'Rice Christian' was coined when the practice became widespread. 'Rice Christians' were people who would claim to be Christians as long as they received the bowl of rice. In a way, it was a kind of benign bribery to get the poor in China to hear the gospel (Richardson 2007:103). Of course, the intention was good. However, the author is of the view that the RCSA should deal with the phenomena of poverty and inequality in terms of provision from the Bible, the Church Order and the forms (especially with regard to the office of the deacons) in an ecclesiastically manner. The most important thing to remember in this regard is that, poverty reduction is not simply to help the poor to meet their daily needs, but to see them transformed by the power of God and empowered to be people of dignity and worth in society (cf. Hiebert \& Meneses 1995:354).

Hence, Christ taught the apostles, just after his resurrection and just prior to his ascension to heaven, 'Go therefore and make disciples of all the nations, baptising them in the name of the Father and of the Son and of the Holy Spirit teaching them to observe all things that I have commanded you' (Mt 28:18-20; Mk 16:15-16). The church's primary concern should be the regeneration and transformation of man through faith in Jesus Christ. In its teaching and preaching ministries towards its members, the church must proclaim the norms of the Kingdom regarding poverty evaluate present conditions locally, nationally and internationally in light of these norms. The church must also call its members to action against situations which are not in accord with these norms Berkhof, 1996:577; Parker 1995:131; Shenk 1993:102). Details cannot be given here about the way in which the church should fulfil this task, but preaching, teaching, Bible studies, prayer sessions and sharing groups will accent the Christian truths about loving, caring, and reaching out in ministry and evangelism (cf. Young 1978:69). 
Training urban churches for effective urban mission: Traditional reformed churches in the urban areas, even those in smaller cities, are declining in numbers. Some are facing enormous demographic shifts and are perplexed as to how to meet the needs of their changing communities (Greenway \& Mashau 2007:20). Different reasons for this sad state of affairs could be identified. One of the most important reasons is that the focus of the RCSA was, and in many places still is, on rural mission whilst the demographic movement of the population is in the opposite direction: away from the rural areas to the cities (McGavran 1988:112; cf. Pierli \& Abeledo 2002:61). Winter and Hawthorne (1999:554) assert that the massive migration to the cities occurring around the world may be, in God's providence, a key to world evangelisation. This means that, to pursue mission within the world's cities, we shall have to rediscover, develop and make known urban mission that speak to people where they live and touch them where they hurt.

Traditionally, the training of pastors did not cater for this need and therefore it remains a great challenge for the RCSA to engage in intensive in-service training for serving ministers if we are to succeed in the challenge posed by poverty in the city. Biblical strategies for growing city churches should be sought, and city workers must be trained for this purpose. Choate (2000:52) notes that to edify means to build up, to strengthen, to encourage and to help the members of the church to grow spiritually. Some of the things that edify are: fellowship, engaging in worship, helpings one another, good works and love (Ac 9:31; Rm 14:19; 1 Cor 8:1; 14:26; 2 Cor 12:19; 1 Th 5:11; cf. Eph 4:12).

\begin{abstract}
A holistic approach (a balanced biblical approach): There is no single way to minister amongst the poor. They are widely diverse in their needs, cultures and abilities to help themselves. This raises a serious question. How should the church respond to those differences? The author is of the opinion that the church in the city must proclaim and live the whole gospel today. It cannot relegate concerns for everyday human needs to the government and expect to be relevant to people (Sanders 1997:141). A holistic ministry aims to bring the whole of humankind into the freedom and dignity found in the value that God attaches to each individual, regardless of gender, physical or mental capacity or racial, geographical or social background. It reaches out to help the needy and speak on behalf of the oppressed (cf. Greenlee 2003:141). Kritzinger and Saayman (1994:36) mention that the various dimensions of this comprehensive approach were expressed in terms of the church's task of kerygma [proclamation], diakonia [ministry of service], koinonia [communion or fellowship], and leitourgia [the public worship service of God].
\end{abstract}

Keeping in mind the clarifications that were discussed, one can formulate a balanced biblical approach as follows: As children of God and disciples of Jesus Christ, Christians should be imitators of Christ and live a Christ-like life of love and holiness. They should show compassion and concern for the lost souls as well as for the poor and needy of this world.
The church must always keep in mind the pre-eminence and the primacy of preaching the gospel. Its primary concern should be the regeneration and transformation of humans through faith in Jesus Christ.

Teaching a Christian work ethic: In today's world, a large percentage of unemployed and poor people are capable of work if they could find it. The efforts of anyone who helps someone to find a job will normally be greatly appreciated, and clearly, a Christian must have the right attitude concerning work so as to avoid being a stumbling block in that process. Paul has a great deal to say on the whole subject of work and how we should treat it.

But we urge you, brethren, that you increase more and more; that you also aspire to lead a quiet life, to mind your own business, and to work with your hands, as we commanded you, that you may walk properly toward those who are outside, and that you may lack nothing (1 Th 4:10-12).

Oliver and Thwaites (2003:30) state that the move to encourage saints regarding their ministry in the world of work is not a new thing. Ministers and theologians of note in the Reformation taught that work was a calling from God. Calvin was probably the strongest in his approach. Like many after him, Calvin believed that each person is called by God to a particular type of work, which, in its outworking, complements the work of others. It is clear that the Bible stresses the importance of Christians working for their living so that they set a good example to all and be dependent on nobody. It is important for the church to affirm the importance of work, to understand the needs of those who are stressed at work and to support those who are unemployed. In other words, if work is important in the society, it should also be important in the church (cf. Stott 2006:230).

Empowering the office of the deacons: In the New Testament, both minister and ministry originate from the word group (diakon in Greek). The verb is diakoneo, meaning 'waiting upon' (Ac 6:2) or serving, or rendering a service. The noun diakonous denotes a waiter at a meal, a servant or attendant. These terms were used in a wider sense, to designate a specific ecclesiastical office such as a 'deacon'. Thus, we see that the words minister and ministry refer to service in general, which may be of a temporary or permanent nature by either a male or female person in an ecclesiastical or non-ecclesiastical capacity (Basu 2005:147).

The work of the deacon was clearly defined in the early church. Acts 2:42 and 4:32-37 describe the mutual care for believers in the congregation of Jerusalem. Initially, the apostles were occupied with this work, but later, as described in Acts 6:1-7, the office of deacon was instituted for this purpose (see Vorster 2003:46). Greenway (1999:186) mentions that deacons are leaders who serve the church in variety of ways, especially by receiving the offering and serving the poor. A comprehensive study conducted in 1991 indicated that the diaconal service of the church is important because of the direct aid that it can give both to those within and outside of the church (Bruwer et al. 1991:16). Towns (2003:103) 
indicates that the office of the deacons must consist not only of financial and material care for destitute people, but the compassion of God in Christ should also find concrete expression in help and aid to ill people, widows and afflicted people and those who need empathy and sympathy (1 Tm 5; cf. 6:10). However, in all instances, the deacon's conduct should be such that people are confronted with Christ and his great mercy and compassion (1 Tm 3:1-13).

With respect to poverty, there are at least three levels at which the church is called to work in diaconal service. The first is in meeting the immediate needs of the poor for food, shelter, medical care and other necessities. The second is in helping the poor to be able to provide for their own needs in future, for example by helping them to obtain skills and employment. These two levels are expressed in the wellknown statement: 'Give a person a fish and you feed him for a day; teach a person to fish and you feed him for a lifetime.' However, the statement is incomplete. Even if people know how to fish, they may not be able to feed themselves if they have no access to the equipment necessary for fishing or if the fishing grounds are owned or controlled by others. This illustrates the fact that a third level of diaconal action is needed, that is, service to change unjust structures which cause poverty, for example a lack of access to adequate education or unjust concentration of control of land and other wealth in a society (Klaiber 1997:222).

The implication for this is that the church, as institution, should call government and other institutions to just actions in accordance with their calling from God. This means that the service we should render need not be limited only to charitable service to the victims of sickness, poverty, disaster, et cetera. However, diaconal service should also serve to correct the structural imbalances and injustices which cause sickness and poverty (Kritzinger \& Saayman 1994:37). Thus, the church should engage in such diaconal service at both the national and the local level. However, the church should do this in humility, confessing its own sins in this regard. Generally, it should not, as an institution, endorse specific legislation, political parties or candidates, or socio-economic-political systems. In its intercession for the country, the church (and individual Christians) should pray for the removal of all injustice and poverty, that the Spirit will guide all those in authority and that they will accept the guidance of the Spirit (cf. Van Engen \& Tiersma 1994:216).

Eckhardt (2010:134) wrote that deacon's ministry has to be strengthened to carry the burden of the local churches. The implications for this are that the relationship between the local congregations of the RCSA and the ecclesiastic structures should be encouraged. The reason for this is that many local churches of the RCSA in the urban areas are declining in numbers, and some are even unable to provide for their own pastors. It is essential to accept the fact that single, comprehensive, economic support for the above-mentioned churches involving the ecclesiastically structures up to the General Synod is necessary, be it in knowledge, self-esteem or financial resources (Greenlee 2003:114). Furthermore, the deacons should request other bodies and institutions that are also devoting themselves to the care of the poor to consult with them to the end that the alms may all the better be distributed amongst those who have the greatest need (Church Order, art. 26).

Christians should organise themselves as an organisation or an institution to help the poor. If the church as an institution is not to speak to the routine political issues of the day, how can Christians reduce poverty in their communities? Monsma (2006:39) states that Christians should organise themselves as an organisation or an institution to help the poor. Moreover, Christian organisations (sometimes called para-church organisations) or a group of churches may need to band together to meet these needs in an appropriate way. Christian NGOs have specific goals, and these goals may include: feeding the hungry; feeding, clothing, and sheltering refuges or disaster victims; protecting the environment; supporting people with chronic illness or disabilities; helping the elderly; and helping the homeless (Schaller 1999:87; Senkhane 2002:26).

Christian NGOs are built on the conviction that God has commanded his church not only to preach the gospel, but to love the peoples of this world unconditionally (Greenlee 2003:140). This should, however, not reduce the diaconal work of the church. The ecclesiastical distinction between the 'church as institute' and the 'church as organisation' that was proposed by Kuyper and applied for many decades in reformed churches worldwide, unfortunately led to the reduction of diaconal work in favour of extra-ecclesiastical charity by other Christian institutions. Cooperation must never lead to the handing over of the diaconal responsibilities of the congregation to other institutions. The church must remain active, because diaconal work is the 'ministry of Christ to the poor' (cf. Vorster 2003:48-49).

Cooperation between the church and state should be encouraged: In nearly all the modern-day views about the duty of the state towards the poor, the caring of the poor is seen as a very important aspect of the functioning of the state. In this field (poverty reduction), the work of the state and the church overlaps. Hence, discussing ways of uprooting poverty is part of the on-going study both by concerned churches and governments, which should lead to effective methods of reducing poverty. Therefore, the cooperation between church and state regarding poverty reduction in the South African urban community must be encouraged (Sekhaulelo 2007:94). However, the church should not be co-opted by political parties, but the church should be more like a stakeholder in holding the government to account. Moreover, the church needs to be vigilant that the government does not trespass on the terrain of the church. Conversely, the church must not interfere with the distinctive task that the government has in this regard.

The task of the South African government towards poverty alleviation entails the introduction of applicable legislation 
(policies) that address socio-economic issues and enhance the care values of the community through, inter alia, quality education, encouraging entrepreneurship through businesses training and mentoring entrepreneurship, improving infrastructure and service in poor community, providing an economic context in which employment opportunities are maximised and providing leadership and coordination for economic growth (cf. Venter 1998:296).

\section{Conclusion}

The essence of this article was to discuss poverty and inequality that plague the urban communities. From the article it clear that the church of Jesus Christ exists primarily to worship and adore God. It must praise his most holy Name. However, it can never use this as a form of escapism. It must take seriously the world that he has created and that he loved so much that he gave his only begotten Son (Jn 3:16). Thus, the church as institution and organism should be a visible expression of the Kingdom to those still in rebellion against it. It should show the good news of reconciliation by the relationships between its members of all social, ethnic and economic groups. This should include the relief of poverty within the Body of Christ. The Kingdom should also be evident in the ways its citizens relate to those outside of it, including its work to relieve poverty in general (Gl 6:10). Finally, the author was able to highlight various strategies, which the RCSA can employ to reduce poverty in the South African urban community.

\section{Acknowledgements Competing interests}

The author declares that he has no financial or personal relationship(s) that may have inappropriately influenced him in writing this article.

\section{References}

Allen, J.L., 1995, Love \& conflict: A covenantal model of Christian ethics, University Press of America, London.

Altbeker, A., 2007, A country at war with itself, Jonathan Ball Publishers, Cape Town. Astley, J., 2000, Choosing life: Christianity and moral problems, Longman and Todd, London.

Balshaw, T. \& Goldberg, J., 2005, Cracking broad based Black Economic Empowerment Human \& Rousseau, Pretoria.

Barclay, W., 1995, Jesus as they saw him, William B. Eerdmans, Grand Rapids.

Basu, K., 2005, The 21st century Christian and his end time mission, OM Books, Secunderabad.

Bauckham, R., 2003, Bible and mission, Baker Academic, Grand Rapids.

Beall, J. \& Fox, S., 2009, Cities and development, Routledge, Abingdon, Oxon.

Berkhof, L., 1996, Systematic theology, Wm. B. Eerdmans Publishing Company, Grand Rapids, MI.

Berkley, J.D., 2000, The dynamics of Church finance, Baker Book House Company, Grand Rapids.

Bernard, D., 2004, City impact, Chosen Books, Rapids, MI.

Biko, H., 2013, The great African society: A plan for a nation gone astray, Jonathan Ball Publishers (Pty) Ltd, Jeppestown.

Bruwer, E., Monsma, G.N., Munane, E. \& Orkar, J.N., 1991, Poverty in Southern Africa, Institute for Reformational Studies, Potchefstroom.

Chanderdeo, A., Pilane, M., Pinnock, A., Strydom, J. \& Viljoen, A., 2011, Platinum business studies: Learner's book 10, Maskew Miller Longman (Pty) Ltd, Pinelands, Cape Town.

Choate, J.C., 2000, The church of the Bible, World Literature Publishing House, Cape Town.
Claerbaut, D., 1983, Urban ministry, Zondervan Publishing House, Grand Rapids, MI. Dake, F.J., 1992, God's plan for man, Dake Bible Sales Inc., Lawrenceville, Georgia. De Bruyn, P.J., 1993, Ethical perspective, Potchefstroom University, Potchefstroom. Douglas, J.D., (ed.), 1990, The new Bible dictionary, InterVarsity Press, Leicester. Eckhardt, J., 2010, Ordinary people extraordinary power, Charisma House, Lake Mary. Feinstein, A., 2007, After the party, Jonathan Ball Publishes, Johannesburg. Forrester, D., 1997, The church and morality: Reflections on ecclesiology and ethics, WCC Publications, Geneva.

Garland, J. \& Blyth, M., 2005, AIDS is real and it is in our church, Jean Garland, Bukuru. Gevisser, M., 2009, Thabo Mbeki: The dream deferred, Jonathan Ball, Publishers, Johannesburg \& Cape Town.

Greenlee, D., 2003, Global passion, OH Books, Secunderabad.

Greenway, R.S., 1999, Discipline the city: A comprehensive approach to urban mission, Library of Phillipsburg, NJ, P \& R Publishing.

Greenway, R.S. \& Mashau, T.D., 2007, An eye that sees: Vision for urban mission, Thitshi Production, Potchefstroom.

Grigg, V., 1990, Christ in the urban slums: Companion to the poor, MARC, Monrovia.

Gumede, W.W., 2005, Thabo Mbeki and the battle for the soul of the ANC, Zebra Press, Cape Town.

Haralambos, M. \& Holborn, M., 1995, Sociology: Themes and perspective, Collins Education, Hammersmith.

Hiebert, P.G. \& Meneses, E., 1995, Incarnational ministry planting churches in 'band', tribal, peasant, and urban societies, Baker Book House Company, Grand Rapids, MI.

Johnson, R.W., 2009, South Africa's brave new world: The beloved country since the end of apartheid, Penguin Books, New York.

Klaiber, W., 1997, Call \& response: Biblical foundation of a theology of evangelism, Abingdon Press, Nashville.

Kritzinger, J.J. \& Saayman, W.A., 1994, On being witnesses, Orion Publishers, Halfway House.

Kuiper, B.K., 1991, The church history, Wm. B. Eerdmans Publishing Co., Grand Rapids, MI

Ladd, G.E., 1993, A theology of the New Testament, Wm. B. Eerdmans Publishing Co., Grand Rapids, MI.

Linthicum, R.C., 1991, City of God: Biblical theology of the urban church, Zondervan Publishing House, Grand Rapids, MI.

Maimela, S. \& König, A., 1998, Initiation into theology: The rich variety of Theology and Hermeneutics, Van Schaik Publishers, Pretoria.

Malan, F. \& Smit, B., 2001, Introduction to comparative politics, Library of Congress, New York.

Mashau, T.D., 2004, 'Hugo du Plessis' contribution to the Reformed Churches' struggle for a relevant mission and missiology', PhD thesis, Dept. of Theology, North-West University.

Mbeki, M., 2011, Advocate for change: How to overcome Africa's challenges, Picador Africa, Johannesburg.

McGavran, D.A., 1988, Effective evangelism: A theology mandate, Library of Congress Cataloguing-in-Publications, New Jersey.

Meredith, M., 2010, Mandela: A biography, Jonathan Ball Publishers, Johannesburg.

Monsma, T.M., 2006, Hope for the Southern world: Impacting societal problems in the non-Western World, CCW Books, Loveland.

Mutavhatsindi, M.T., 2008, Church planting in the South African urban context: With special reference to the Reformed Church Tshiawelo, University of Pretoria, Pretoria.

Oliver, D. \& Thwaites, J., 2001, Church that works, Word Publishing, Milton.

Parker, T.H.L., 1995, Calvin: An introduction to his thought, Mackays of Chatham, London.

Pawson, J.D., 2007, Unlocking the Bible: A unique overview of the whole Bible, Collins Publishers, London.

Peters, G.W., 1976, A biblical theology of mission, Moody Press, Chicago.

Pierli, E. \& Abeledo, Y., 2002, The slums: A challenge to evangelisation, Kolbe Press, Limuru.

Plaut, M. \& Holden, P., 2012, Who rules South Africa? Pulling the strings in the battle for power, Jonathan Ball Publishers, Johannesburg.

Pottinger, B., 2008, The Mbeki legacy, Zebras Press, Cape Town.

Ramphele, M., 2012, Conversations with my sons and daughters, Penguin Group, Johannesburg.

Richardson, J., 2007, Can you spare a bit of chance?, Authentic Books, London.

Sanders, C.J., 1997, Ministry at the margins: The prophetic mission of women, youth and the poor, InterVarsity Press, Downers Grove, Illinois.

Schaller, L.E., 1999, One church, many congregations: The key church strategy, Abingdon Press, Nashville.

Sekhaulelo, M.A., 2007, 'The calling of the church in the moral renewal of the South African urban community', MA dissertation, Dept. of Theology, North-West University.

Senkhane, M.M., 2002, 'The role of biblical counselling in rebuilding the "Poortjie" informal settlements', MA dissertation, Dept. of Theology, PU for CHE, Potchefstroom. 
Shenk, W.R., 1993, The transfiguration of mission: Biblical theological \& historical foundation, Herald Press, Scottdale.

Shively, W.P., 1997, Power \& choice: An introduction to political science, McGraw-Hill, Minnesota.

Silvoso, E.D., 2007, Transformation: Change market place and you change the world, Regal Books, Ventura, California.

Stott, J., 2006, Issues facing Christians today, Zondervan, Grand Rapids, Michigan.

Strydom, J.G. \& Wessels, W.J., 2000, Prophetic perspective on power and social justice, Biblia Publishers, Pretoria.

Tonna, B., 1982, Gospel for the cities, Orbis Books, Maryknoll, NY.

Towns, E.L., 2003, Bible answers for almost all your questions, Thomas Nelson Inc. Nashville, Tennessee.

Van der Walt, B.J., 1991, Anatomy of reformation: Flashes and fragments of a reformational worldview, $\mathrm{PU}$ for $\mathrm{CHE}$, Potchefstroom.

Van der Walt, B.J., 1994, Man and God: A reformational philosophy of religion, PU for $\mathrm{CHE}$, Potchefstroom.

Van der Walt, B.J., 2007, Transforming power: Challenging contemporary secular society, Institute for contemporary Christianity in Africa, Potchefstroom.
Van Engen, C. \& Tiersma, J., 1994, God so love the City: Seeking theology for urban mission, MARC, Monrovia, California.

Venter, A., 1998, Government politics in the new South Africa, Van Schaik Publishers, Pretoria.

Vorster, J.M., 2003, An introduction to Reformed Church Polity, Potchefstroom Theological Publications, Potchefstroom.

Vorster, N., 2007, Restoring human dignity in South Africa, Potchefstroom Theological Publications, Potchefstroom.

Williams, D.T., 1998, Capitalism, socialism, Christianity \& poverty, Van Schaik Publishers, Pretoria.

Winter, R.D. \& Hawthorne, S.C., 1999, Perspectives on the world Christian movement Institute of International Studies, Pasadena, California.

Wright, J.H., 1995, Walking in the ways of the Lord: The ethical authority of the Old Testament, InterVarsity Press, Downers Grove, Illinois.

Yandian, B., 1985, The Spirit controlled life, Whitaker House, Springdale.

Young, E.J., 1978, An introduction to the Old Testament, Eerdmans Printing Press, Grand Rapids, Michigan. 